\section{HISTÓRIA DA FEBRE AMARELA NO BRASIL}

A pesquisa trata da história da febre amarela no Brasil e parte de uma premissa geral: a febre amarela é fruto de um processo a um só tempo biológico e social, cuja historicidade tem a ver com os tempos inerentes às sociedades humanas e com os ciclos próprios à organização de outros seres, macro ou microscópicos.

Algumas correlações balizam o estudos: com que intensidade e duração ela se abateu sobre as coletividades humanas ao longo do tempo? Que influência exerceu sobre atividades econômicas, organização social e vivências coletivas e individuais dos homens? Que teorias, conceitos, representações e metáforas foram formuladas para explicá-la?

Com relação aos marcos cronológicos, a idéia inicial era retroagir até a primeira grande epidemia ocorrida na capital do Império, em 1849-50, e avançar até o ano de 1958, quando se considerou a febre amarela controlada nacionalmente. Mas, como seria de se esperar, a prática encarregou-se de erodir essa ambição desmedida e de redefinir as questões que conformavam o projeto de pesquisa. A documentação primária do primeiro período revelou-se tão vasta e fascinante que se tornou inevitável prolongar a estadia na segunda metade do século passado. Contribuiu, também, o fato de o universo das fontes secundárias se haver revelado muito mais denso para este período.

Ao cabo de alguns meses, foi elaborada uma resenha do que se escreveu, contemporaneamente, sobre a febre amarela, sobretudo nas décảdas de 1880-1900. Concomitantemente, foram recuperados os debates ocorridos na Academia Imperial - depois Nacional - de Medicina, onde a febre amarela teve considerável peso relativo entre os temas ali tratados. O objetivo era identificar os deslocamentos conceituais ocasionados pela difusão da revolução pasteuriana; mais especificamente, o impacto produzido pelos trabalhos daqueles médicos que reivindicaram a descoberta do germe da febre amarela. Uma terceira meta era verificar de que maneira as disputas de natureza teórica e conceitual se entrelaçavam com o saneamento do Rio de Janeiro; para tal, foram consultados os códices do Arquivo Geral da Cidade do Rio de Janeiro.

Em fins do século passado, as controvérsias sobre a etiologia e profilaxia da febre amarela opuseram médicos que defenderam teorias concomitantes ou sucessivas, muitos deles oriundos da América Central e do Sul, outros de instituições européias e norte-americanas. Estes últimos foram chamados a - ou se arrogaram ao direito de - controlar os resultados obtidos pelos concorrentes sul-americanos.

Segundo François Delaporte (Histoire de la fière jaune, Paris, Payot, 1989, p. 77), com a descoberta das vacinas contra o cólera das galinhas e o carbúnculo, por Pasteur, a doutrina parasitária rapidamente transformouse, na percepção dos contemporâneos, em prática salvadora da humanidade. Os médicos têm consciência de viver uma revolução, consciência esta que logo alcança o Novo Mundo, onde "rapidamente os estudos relacionados à febre amarela passam a gravitar em torno do parasitismo". Transposta para o novo cenário, a ênfase nas vacinas serve para destacar, a um só tempo, a motivação dos médicos sul-americanos - "cada um sonhava impor-se como o Pasteur dos trópicos" - e também a vulnerabilidade principal de seus trabalhos: "A esperança de obter vírus atenuados explica a rapidez com que darão corpo ao germe amarílico."

Os médicos que tentaram implementar o programa da nova ciência - observar o germe, descrever suas propriedades e ação patogênicas e atenuar sua virulência para ob- 
ter uma vacina contra a doença - tiveram de lutar em duas frentes simultaneamente. De um lado, obter o reconhecimento das instituições hegemônicas no cenário biomédico internacional; de outro, conquistar legitimidade para este programa no cenário interno, ainda dominado por um paradigma anterior ao da nova ciência que conferia grande força de inércia às instituições, mentalidades e práticas sociais.

A hipótese a ser verificada é a de que a ciência dos micróbios converteu-se no pólo mais dinâmico da medicina brasileira, em larga medida por obra dos postulantes de teorias etiológicas desqualificadas nos fóruns médicos internacionais. Isso implica retificar o juízo negativo que os autores atuais fazem dos trabalhos realizados pelos primeiros bacteriologistas sul-americanos, endossando, uns mais, outros menos, as representaçōes que, na época, subjazem as controvérsias $\mathrm{e}$ influem em seu desenrolar: de um lado, médicos entusiastas, porém mal preparados, ignorantes das técnicas da microbiologia; de outro, sábios que dominam plenamente a teoria e a prática científicas modernas.

Um artigo de Margaret Warner ('Hunting the yellow fever germ: the principle and practice of etiological proof in late nineteenthcentury America', Bulletin of the History of Medicine [59]: 361-83) forneceu elementos valiosos para a análise. De acordo com a autora, as descobertas eram julgadas segundo dois conjuntos interligados de critérios que provinham de duas tradições diferentes: a bacteriologia e a epidemiologia. Havia consenso entre os postulantes das teorias em disputa quanto ao fato de que, para ser aceito, o germe tinha de satisfazer as rigorosas regras de verificação formuladas por Robert Koch. Por outro lado, era preciso explicar os fatos oriundos dos estudos epidemiológicos e da observação clínica.

Daí se deduz a existência de dois círculos. No interior do primeiro, que circunscreve o campo da bacteriologia, confrontam-se para usar uma imagem de Bruno Latour laboratórios e contra-laboratórios que disputam teorias rivais acerca do germe e que não apenas endossam e fortalecem os postulados de Koch, como estão mais ou menos providos dos meios para implementá-los. Na linguagem kuhniana, habitam este círculo os convertidos ao paradigma pasteuriano que se dedicam à resolução dos enigmas propostos por ele, em conformidade com regras que também derivam deste paradigma. No círculo mais amplo, encontram-se os clínicos e higienistas que não têm familiaridade com a bacteriologia e que precisam ser persuadidos. A disputa, aqui, refere-se à compatibilidade das soluções propostas para o enigma com os corpos empírico-conceituais da epidemiologia e da clínica.

Nos textos extraídos dos Anais da Academia de Medicina, três percepções da febre amarela puderam ser depreendidas. Uma é a do higienista, cuja reflexão está voltada para as causas, cósmicas e sócio-históricas, das epidemias e para os obstáculos que impedem a neutralização dessas causas. A segunda é a percepção do clínico, que estrutura o conhecimento da febre amarela segundo um modelo que correlaciona descrição dos sintomas, identificação e interpretação dos processos fisiológicos e das lesões orgânicas (necropsias) subjacentes a eles, e experimentação terapêutica. A terceira percepção é a dos médicos que, no laboratório, reestruturam e reinterpretam a doença à luz da teoria de Pasteur: causa microbiana, especificidade etiológica, eventual imunização.

Da leitura dos documentos publicados nos Anais da Academia, foram inferidas outras observações relativas à interação destas três percepções ou modelos de interpretação da febre amarela:

$a$. O clínico e o higienista não definem categorias sociais estanques. São papéis encarnados, muitas vezes, pelas mesmas pessoas. Embora os médicos desempenhem ambos os papéis em fóruns como a Academia, remetem a lugares e práticas específicas: hospitais de isolamento ou gerais e clínica privada, de um lado; aparelhos institucionais da higiene, de outro.

$b$. Independentemente das relações de oposição ou afinidade existentes entre as três 
percepções, cada uma delas abarca controvérsias que lhes são específicas.

c. Os documentos expressam momentos particulares na interação de atores do campo médico. Para compreender seus posicionamentos, temos de nos reportar aos momentos particulares do devir da medicina e da ciência dos micróbios, que não constituíam, nem aqui nem nas formações sociais mais avançadas, 'pacotes' acabados de postulações auto-evidentes. A entronização da medicina pasteuriana no Brasil não pode ser encarada como assimilação passiva de idéias oriundas de países econômica e culturalmente hegemônicos.

d. Na década de 1890 , já era um princípio tacitamente aceito por todos que a febre amarela era causada por um germe específico. Nesse contexto, questões que eram objeto de polêmicas antigas, como a natureza contagiosa ou não da febre amarela, a imunidade dos nativos etc., adquiriram novos conteúdos. Por outro lado, o consenso básico que existia quanto ao repertório de ações para sanear as cidades deu lugar a controvérsias inéditas com relação à identificação dos elos mais frágeis a romper na cadeia da insalubridade, pondo em questão, por um lado, as supostas propriedades do germe, por outro, os múltiplos interesses dos atores envolvidos no saneamento.

$e$. As fontes secundárias haviam levado à hipótese de que os médicos brasileiros engajados no programa pasteuriano lutaram em duas frentes simultaneamente. Os documentos corroboraram esta hipótese e levaram a um terceiro cenário relevante. Lá fora, os debates transcorriam em fóruns considerados legítimos, ao menos na perspectiva dos médicos brasileiros. No Brasil, especificamente no Rio de Janeiro, o debate extravasava em larga medida as instituições médicas e transcorria na imprensa diária, perante atores 'profanos' que intervinham, ativa ou passivamente, no desenrolar das controvérsias científicas.

Depois de chegar a tais resultados, foi ampliada a pesquisa de fontes primárias, sendo rastreadas (na Biblioteca Nacional, no Museu Nacional, na Biblioteca do Centro de Ciências da Saúde e ainda na Academia de Medicina) as trajetórias de dois bacteriologistas notáveis,
Domingos José Freire e João Batista de Lacerda. Além de se recuperarem as polêmicas protagonizadas por ambos, foram submetidos a um 'pente fino' o Jornal do Commercio e a Gazeta de Notícias, colhendo-se aí todas as notícias sobre a febre amarela publicadas entre 1880 e 1884, em particular sobre as repercussões da vacina descoberta por Freire em 1882-83.

Seguindo as pegadas deste personagem indiscutivelmente o mais controvertido - foi possível enxergar melhor a geopolítica da prática médica no último quarto do século passado. Semelhante investimento de pesquisa será dedicado a João Batista de Lacerda, tendo em vista a possibilidade de desenvolver contrapontos com Domingos José Freire, sobretudo no que concerne às posturas éticas e às suas estratégias profissionais. Lacerda privilegiou sempre os fóruns acadêmicos e, nos momentos críticos de confrontação, adotou atitudes conciliadoras, procurando salvar do naufrágio suas verdades aproximando-as das idéias dos concorrentes. Freire nunca teve escrúpulos em buscar aliados fora dos muros da academia, e nos momentos críticos adotou, invariavelmente, uma tática de confrontação, a defesa sempre intransigente de suas próprias verdades.

Num texto intermediário demonstrou-se a lenta desconstrução do Instituto Bacteriológico Domingos Freire, que nasceu como portador de um ambicioso programa de pesquisas e feneceu, junto com o próprio Freire, como melancólica sinecura. Destaca-se o anacronismo de seus derradeiros trabalhos, em tudo simétricos àqueles da velha higiene dos miasmas: minuciosas medições do meio ambiente e da atmosfera para detectar influências sobre a patogenicidade dos micróbios em suspensão no ar.

Outra hipótese de trabalho vem se revelando frutífera: este instituto poderia ser encarado como o canto do cisne de uma geração de bacteriologistas que foi expurgada da história e da tradição médicas brasileiras por um grupo que pertence já a outra geração de médicos. Tal hipótese se coloca nos termos que veremos a seguir. 
Ao invés de interpretar a era oswaldiana como momento de superação da obsoleta teoria dos miasmas pela moderna ciência dos micróbios, a geração de Oswaldo Cruz notabilizou-se por romper com os primeiros bacteriologistas brasileiros e com uma geração de médicos que já se havia convertido, majoritariamente, à teoria pasteuriana. Oswaldo Cruz e o grupo de cientistas/sanitaristas que nucleou entraram em cena dispostos a fazer tabula rasa das experiências acumuladas para inaugurar uma era de 'regeneração' da medicina e da ciência experimental. Expressão disso é uma solução de continuidade, nos planos sócio-organizacional e cognitivo, como nunca havia ocorrido e não ocorreria mais depois.

O grupo de Oswaldo Cruz conquistou proeminência renovando ou criando instituições que se mantiveram por longo tempo em conflito declarado com os fóruns tradicionais do campo médico. Gerou safra abundante de trabalhos científicos nos quais são reduzidíssimas as referências aos autores nacionais que produziram antes. Veiculou discursos, ou foi objeto dos mesmos, que primava pela preocupação de demarcar rupturas com o passado, ignorando-o ou apostrofando-o, e de enaltecer a fundação de uma época nova.

Pesquisas subseqüentes em fontes primárias reforçaram tal convicção. Em periódicos do final do século, em particular no Jornal do Commercio e em O Paiz, estão registradas as derradeiras controvérsias em que Domingos Freire esteve envolvido. Uma originou-se de epidemia que causou grandes estragos no Rio de Janeiro em 1892. Freire diagnosticou-a como "febre biliosa dos países tropicais" e publicou em francês a descoberta do bacilo que era seu agente etiológico. $\mathrm{Na}$ mesma ocasião, Francisco Fajardo defendeu a tese de que se tratava de impaludismo, assumindo no Brasil a condição de redesco- bridor do plasmódio recém-descoberto por Laveran.

À semelhança de episódios anteriores, o palco onde transcorreu boa parte da disputa foi a imprensa diária, mas agora ela se revestia de tamanha complexidade que quase só intervinham especialistas. Ao lado de Freire, perfilaram-se médicos encanecidos que se declaravam indignados com aqueles jovens que julgavam saber tudo de bacteriologia. Ao lado de Fajardo, encontramos muitos dos personagens que mais tarde vão ocupar o panteão oswaldiano. Além do próprio Oswaldo Cruz, sobressaíam Carlos Seidl, Chapot Prévost e Adolfo Lutz. Cabe lembrar que Francisco Fajardo figura nas biografias do "fundador da medicina científica brasileira" como o mestre que o persuadiu a se especializar no Instituto Pasteur de Paris. E, nas biografias de Carlos Chagas, como seu iniciador nos estudos sobre o impaludismo.

Domingos Freire sustentou o fogo dos adversários até a sua morte, episódio documentado na imprensa leiga e especializada. Apesar de suas idéias estarem desacreditadas, o tempestuoso personagem foi sepultado com honras de herói - herói de uma ciência brasileira. Mesmo os adversários encarniçados da véspera renderam homenagens à determinação com que este jacobino defendera suas idéias. Mas isso não impediu que fosse virtualmente expurgado de nossa historiografia médica.

Um detalhe sugestivo: a Academia $\mathrm{Na}$ cional de Medicina realizou conturbada sessão para decidir se prestava ou não homenagens especiais a Domingos Freire, que chegara ao ponto de renunciar publicamente ao título de membro titular. Findo o debate, foi admitido no recinto um jovem para ser aclamado o mais novo membro titular da vetusta corporação: era Oswaldo Cruz.

Jaime Larry Benchimol Casa de Oswaldo Cruz, fevereiro de 1994 